JURNAL PENGABDIAN PADA MASYARAKAT ISSN 2540-8739 (print) || ISSN 2540-8747 (online)

LEMBAGA PENELITIAN, PENGABDIAN, DAN PENGEMBANGAN MASYARAKAT UNIVERSITAS MATHLA'UL ANWAR BANTEN

\title{
Pelatihan Penulisan Artikel Ilmiah: Menuju Guru Berkualitas
}

\author{
Nine Febrie Novitasari ${ }^{1}$ \\ ${ }^{1}$ Universitas Abdurachman Saleh Situbondo
}

\begin{tabular}{|c|c|}
\hline Article History & ABSTRACT \\
\hline \multirow[t]{2}{*}{$\begin{array}{l}\text { Received } 18.05 .2019 \\
\text { Received in revised form } \\
03.09 .2019 \\
\text { Accepted } 04.10 .2019 \\
\text { Available online } 28.10 .2019\end{array}$} & $\begin{array}{l}\text { PROGRAM OF SCIENTIFIC ARTICLE WRITING TRAINING: TOWARDS } \\
\text { QUALIFIED TEACHERS. Writing scientific articles is one of teacher' efforts to } \\
\text { improve their quality and develop their professionalism. Unfortunately, their } \\
\text { reading interest and wriitng habit are still low. This makes the teachers have } \\
\text { difficulties when they have to submit a promotion because they do not have } \\
\text { enough background knowledge and understanding in writing scientific articles, } \\
\text { while one of the requirements for submitting a promotion is to publish a scientific } \\
\text { article. Therefore, a training on scientific article writing was held for teachers in } \\
\text { Situbondo to provide knowledge and skills for them to write scientific articles. } \\
\text { After participating in this activity, teachers are expected to be able to publish } \\
\text { scientific articles and be able to improve the quality and professionalism of their } \\
\text { work so that the quality of education becomes better. }\end{array}$ \\
\hline & KEYWORDS: Situbondo, Scientific Articles, Teachers, Training, Workshop. \\
\hline
\end{tabular}

DOI: 10.30653/002.201943.152

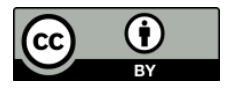

This is an open access article distributed under the terms of the Creative Commons Attribution 4.0 International License, which permits unrestricted use, distribution, and reproduction in any medium, provided the original work is properly cited. ○) 2019 Nine Febrie Novitasari.

\section{PENDAHULUAN}

Artikel ilmiah menurut Budiyanto (2007) adalah karya tulis ilmiah yang disusun berdasarkan hasil penelitian yang diterbitkan di dalam jurnal atau majalah ilmiah. Artikel ilmiah biasanya memiliki aturan penulisan tersendiri. Sumber bahan untuk menulis artikel ilmiah dapat berupa laporan hasil penelitian, kumpulan makalah, buku dan diktat/bahan ajar, serta laporan kegiatan pengembangan proyek (Nailun, 2018). Menulis artikel ilmiah bagi kalangan akademisi bukanlah hal yang asing. Beberapa akademisi seperti mahasiswa, guru, dan dosen memiliki kewajiban untuk membuat artikel ilmiah sebagai prasyarat kelulusan, kenaikan pangkat, ataupun persyaratan tri dharma pendidikan. Namun, tidak semua akademisi memiliki kemampuan yang baik dalam menulis sebuah artikel ilmiah.

\footnotetext{
${ }^{1}$ Corresponding author: Program Studi Sastra Inggris, Fakultas Ssatra Universitas Abdurachman Saleh Situbondo; Jl. PB. Sudirman No. 7
} Patokan, Situbondo; Email: ninefebrie@gmail.com 
Adanya Permeneg Pendayagunaan Aparatur Negara dan Reformasi Birokrasi No.16 Tahun 2009 secara tidak langsung memberikan imbas terhadap jabatan guru dan pengusulan kenaikan pangkat melalui penetapan angka kredit. Peraturan baru ini terdiri dari 13 Bab dan 47 pasal secara keseluruhan mengandung semangat yang bertujuan untuk meningkatkan kompetensi dan profesionalisme guru sebagai tenaga profesional yang mempunyai fungsi untuk meningkatkan mutu pendidikan nasional sebagaimana diamanatkan dalam Undang-undang No. 14 Tahun 2005 Pasal 4. Persyaratan untuk meningkatkan profesionalisme guru antara lain adalah adanya kewajiban bagi guru golongan III/b untuk membuat publikasi ilmiah atau karya inovatif. Kewajiban lain yang dianggap momok adalah dalam pengusulan kenaikan pangkat dan jabatan guru dari golongan IV/a ke IV/b. Mereka yang akan mengajukan kenaikan pangkat wajib untuk menyerahkan minimal satu karya tulis hasil penelitian dan satu artikel yang terbit di jurnal (Raharja, 2015).

Permasalahan muncul karena tidak adanya kebiasaan dan budaya menulis yang dimiliki oleh guru. Akibatnya, banyak ditemukan pelanggaran seperti plagiasi atau calo artikel dimana guru yang akan mengajukan pangkat tersebut meminta orang lain dan membayar sejumah uang untuk dibuatkan artikel ilmiah. Alasan lain mengapa menulis artikel ilmiah bagi guru menjadi suatu hal yang sulit dilakukan karena tidak adanya kegiatan yang dapat memfasilitasi guru untuk menghasilkan suatu karya ilmiah. Tidak ada sosialisasi atau pelatihan tentang melaksanakan penelitian dan publikasi karya ilmiah. Akibatnya, menulis artikel ilmiah menjadi hal yang tidak familiar. Lokasi sekolah dan domisili guru juga menjadi penentu sulitnya guru menulis artikel ilmiah. Guru yang tinggal di kota lebih mudah memiliki akses untuk Internet ataupun buku referensi. Namun, mereka yang letak tempat tinggal dan sekolahnya jauh dari kota dan terletak di daerah terpencil akan sangat mengalami kesulitan dalam mengakses teknologi dan buku referensi. Maka, semakin sulitlah kesempatan mereka untuk naik pangkat karena keterbatasan yang ada. Namun, dalam beberapa kasus, adanya teknologi yang harusnya mempermudah guru untuk dalam proses penelitian, mencari sumber dan bahan pustaka dan publikasi malah disalahgunakan sebagai solusi cepat menulis artikel dengan cara memplagiasi tulisan orang lain.

Seyogyanya, menulis karya ilmiah seperti artikel ilmiah adalah bukan sekedar pemenuhan persyaratan kenaikan pangkat/jabatan. Menulis karya ilmiah dan berbagai kegiatan pengembangan profesi lainnya sebaiknya dilakukan oleh para guru sebagai anggota profesi. Hal ini didukung oleh pernyataan dari menulis karya ilmiah adalah salah satu bentuk pengembangan keprofesian berkelanjutan dari guru (Trisniawati dkk, 2018). Selain itu, hasil penelitian guru yang dipublikasikan dalam artikel ilmiah juga dapat bermanfaat baik secara teoritis maupun praktis sehingga bermanfaat bagi dunia pendidikan. Hal ini sejalan dengan pendapat dari beberapa sumber lainnya (Aina dkk, 2015; Danawati, 2017; Dewi dkk, 2018). Mereka menjabarkan bahwa profesionalisme guru dapat dilihat dari berapa banyak publikasi ilmiah yang mereka hasilkan. Proses menulis karya ilmiah adalah sebuah upaya pengoptimalisasian wujud profesionalisme mereka. Maka dari itu, tulisan-tulisan ilmiah yang dihasilkan guru juga sekaligus menunjukkan upaya-upaya guru dalam meningkatkan kualitas pembelajaran di sekolahnya (Gunawan dkk, 2018).

Kesulitan dalam membuat sebuah artikel ilmiah sebagai persyaratan kenaikan pangkat juga terjadi pada guru PNS di Kabupaten Situbondo. Selama ini, proses kenaikan 
pangkat guru tidak terjadi secara rutin. Artinya, dikarenakan kesulitan dalam menulis artikel ilmiah, ada guru yang tidak segera mengajukan kenaikan pangkat selama bertahun-tahun. Selain itu, cara yang terkadang ditempuh adalah membuat artikel ilmiah apa adanya tanpa memperhatikan kaidah penulisan artikel ilmiah yang baik dan benar. Dari survey yang sempat dilakukan, fakta ini terjadi pada guru PNS di banyak sekolah, baik sekolah di daerah perkotaan maupun sekolah-sekolah di daerah pinggiran. Kebanyakan guru tersebut tidak memiliki pemahaman yang baik tentang manfaat dan sistematika penulisan artikel ilmiah.

Jika diidentifikasi dan dirangkum, identifikasi permasalahan seperti yang telah dijelaskan sebelumnya, kesulitan dalam menulis artikel ilmiah terjadi karena beberapa penyebab, salah satunya adalah budaya membaca dan menulis yang rendah, dan kurangnya sosialisasi dari pihak-pihak terkait kepada guru-guru untuk giat menulis artikel ilmiah. Akibatnya, pelanggaran etik terkadang muncul saat guru harus menulis artikel ilmiah sebagai syarat mengajukan kenaikan pangkat. Bila dianalisis, pelanggaranpelanggaran ini berasal dari cara berpikir yang salah dalam menyikapi adanya kewajiban dalam penulisan artikel ilmiah. Pola pikir yang baik tentang penulisan artikel ilmiah sejatinya harus sudah ditanamkan bahkan oleh guru yang belum menjadi PNS sekalipun. Melihat fakta tersebut, kami berinisiatif untuk memberikan pelatihan penulisan artikel ilmiah bagi guru (PNS dan guru kontrak/GTT) di Kabupaten Situbondo. Tujuan dari adanya pelatihan ini adalah agar mereka memiliki keterampilan menulis artikel ilmiah yang baik sejak dini dan dapat meningkatkan kualitas diri dan profesionalisme kerjanya.

Beberapa kegiatan sejenis pernah dilaksanakan di beberapa daerah dengan latar belakang yang cukup berbeda namun memiliki tujuan yang sama, yaitu meningkatkan kualitas dan profesionalisme guru. Ilfiandra dkk (2016) mengadakan pelatihan dan pendampingan penulisan karya ilmiah bagi guru SD di Kabupaten Tasikmalaya. Kegiatan ini mengkhususkan pada pelatihan dan pendampingan penulisan Penelitian Tindakan Kelas (PTK). Selain itu, Imswatama dkk (2018) mengadakan pendampingan penyusunan karya ilmiah dalam bentuk pelatihan bagi guru SMP Negeri 7 Kota Sukabumi. Pendampingan ini dilaksanakan atas dasar minimnya jumlah sumber informasi, waktu untuk menulis, dan pengetahuan guru terkait karya ilmiah. Sumartini dkk (2019) mengadakan workshop penulisan karya ilmiah bagi guru SD di Kabupaten Demak. Kegiatan yang dilaksanakan terdiri dari pelatihan dan sesi konsultasi.

Berdasarkan keberhasilan dan efektifitas kegiatan-kegiatan tersebut, maka kegiatan sejenis diadakan bagi guru-guru di Kabupaten Situbondo. Secara khusus kami menggandeng SDN 1 Sumberargo sebagai mitra kegiatan. SDN 1 Sumberargo adalah salah satu sekolah negeri yang terletak di daerah terpencil. Sekolah ini beralamat di Dusun Krajan, RT 1 RW 1, Desa Sumberargo Kecamatan Sumbermalang, Kabupaten Situbondo (Dapodikdasmen, 2018). Berdasarkan Peraturan Presiden Nomor 131 Tahun 2015 tentang Penetapan Daerah Tertinggal Tahun 2015-2019, Kabupaten Situbondo termasuk salah satu kabupaten dari 122 kabupaten di Indonesia yang ditetapkan sebagai kabupaten 3T (tertinggal, terluar, terdepan). Situbondo ditetapkan sebagai kabupaten tertinggal berdasarkan kriteria sebagai berikut: a. perekonomian masyarakat; $b$. sumber daya manusia; c. sarana dan prasarana; d. kemampuan keuangan daerah; e. aksesibilitas; dan f. karakteristik daerah. SDN 1 Sumberargo memiliki dua belas orang tenaga pendidik. Pemilihan SDN 1 Sumberrago sebagai mitra adalah berdasarkan adanya temuan bahwa 
guru-guru di sekolah ini hampir semuanya tidak memiliki cukup pemahaman tentang artikel ilmiah, sehingga mereka tidak dapat mengajukan kenaikan pangkat secara rutin.

\section{METODE PELAKSANAAN}

Permasalahan dari pemahaman kurang yang dimiliki guru tentang pentingnya menulis artikel ilmiah, konsep dan prosedur penulisan artikel ilmiah yang benar, dan keterampilan menulis artikel ilmiah, maka solusi yang diberikan adalah dengan memberikan pelatihan dan pendampingan penulisan artikel ilmiah bagi guru-guru di Situbondo. Pada pelatihan ini, secara spesifik, guru sebagai peserta pelatihan akan diberikan gambaran tentang pentingnya menulis artikel ilmiah, sistematika penulisan artikel ilmiah, dan pendampingan khusus untuk membuat artikel ilmiah. Bila dirangkum, Tabel 1 mendeskripsikan permasalahan dan solusi yang kami tawarkan dalam kegiatan PKM ini.

Tabel 1. Daftar Permasalahan dan Solusi yang Ditawarkan

\begin{tabular}{llll}
\hline No. & Permasalahan & Solusi & Keterangan \\
\hline 1. & $\begin{array}{l}\text { Guru tidak memahami } \\
\text { pentingnya menulis } \\
\text { artikel ilmiah. }\end{array}$ & $\begin{array}{l}\text { Memberikan } \\
\text { pemahaman kepada } \\
\text { guru tentang } \\
\text { pentingnya menulis } \\
\text { artikel ilmiah }\end{array}$ & $\begin{array}{l}\text { Pemahaman berupa referensi } \\
\text { tentang manfaat dan } \\
\text { kebiasaan membuat karya } \\
\text { ilmiah, termasuk artikel } \\
\text { ilmiah. }\end{array}$ \\
\hline 2 & $\begin{array}{l}\text { Guru tidak memahami } \\
\text { konsep dan prosedur } \\
\text { penulisan artikel ilmiah } \\
\text { yang benar. }\end{array}$ & $\begin{array}{l}\text { Memberikan pelatihan } \\
\text { penulisan artikel } \\
\text { ilmiah. }\end{array}$ & $\begin{array}{l}\text { Pelatihan berupa pemberian } \\
\text { materi tentang sistematika } \\
\text { dan bagian-bagian dari } \\
\text { artikel ilmiah. }\end{array}$ \\
\hline 3 & $\begin{array}{l}\text { Guru tidak memiliki } \\
\text { keterampilan untuk } \\
\text { menulis artikel ilmih. }\end{array}$ & $\begin{array}{l}\text { Memberikan } \\
\text { pendampingan selama } \\
\text { proses penulisan artikel } \\
\text { ilmiah. }\end{array}$ & $\begin{array}{l}\text { Pendampingan berupa } \\
\text { pemberian saran dan } \\
\text { masukan dalam } \\
\text { menghasilkan sebuah artikel } \\
\text { ilmiah. }\end{array}$ \\
\hline
\end{tabular}

Secara spesifik, dalam pelaksanaan kegiatan PKM ini, metode-metode yang akan diterapkan dibagi menjadi 2 (dua) yaitu tahapan pelatihan dan tahapan pendampingan. Tahap pelatihan adalah tahap dimana kami memberikan informasi dan gambaran tentang manfaat dan sistematika penulisan artikel ilmiah. Tahapan ini dilaksanakan selama satu hari. Target dari tahapan ini adalah memberikan pemahaman kepada guru tentang pentingnya menulis artikel ilmiah. Peserta pelatihan yaitu guru, harus mengerti bahwa menulis artikel ilmiah bukanlah sekedar persyaratan dalam pengajuan kenaikan pangkat. Mereka juga harus diberi pemahaman bahwa menulis artikel ilmiah adalah salah satu upya untuk mengembangkan diri, meningkatkan kualitas diri, dan salah satu upaya menunjukkan profesionalisme kerja. Selain itu, di sini peserta pelatihan diberikan gambaran tentang, jenis-jenis penelitian, struktur penulisan artikel ilmiah, bentuk-bentuk pelanggaran kode etik dalam penulisan artikel ilmiah, dan bagaimana cara menghindarinya. Dalam tahapan ini, peserta pelatihan juga diberi sesi praktik untuk berlatih merumuskan masalah penelitian, menyusun kerangka metode penelitian, menuliskan kutipan atau sitasi, merangkum, memparafrase, dan menuliskan daftar pustaka. 
Pada tahapan kedua yaitu tahapan pendampingan, dimana peserta pelatihan diberikan waktu 3 (tiga) minggu untuk membuat artikel ilmiah di rumah. Selama sesi pendampingan, peserta bisa mengajukan konsultasi baik secara langsung maupun melalui WhatssApp atau e-mail untuk membantu mereka dalam membuat artikel ilmiah. Gambaran tentang pelaksanaan kegiatan dan luaran yang diharapkan dapat dilihat pada Gambar 1.

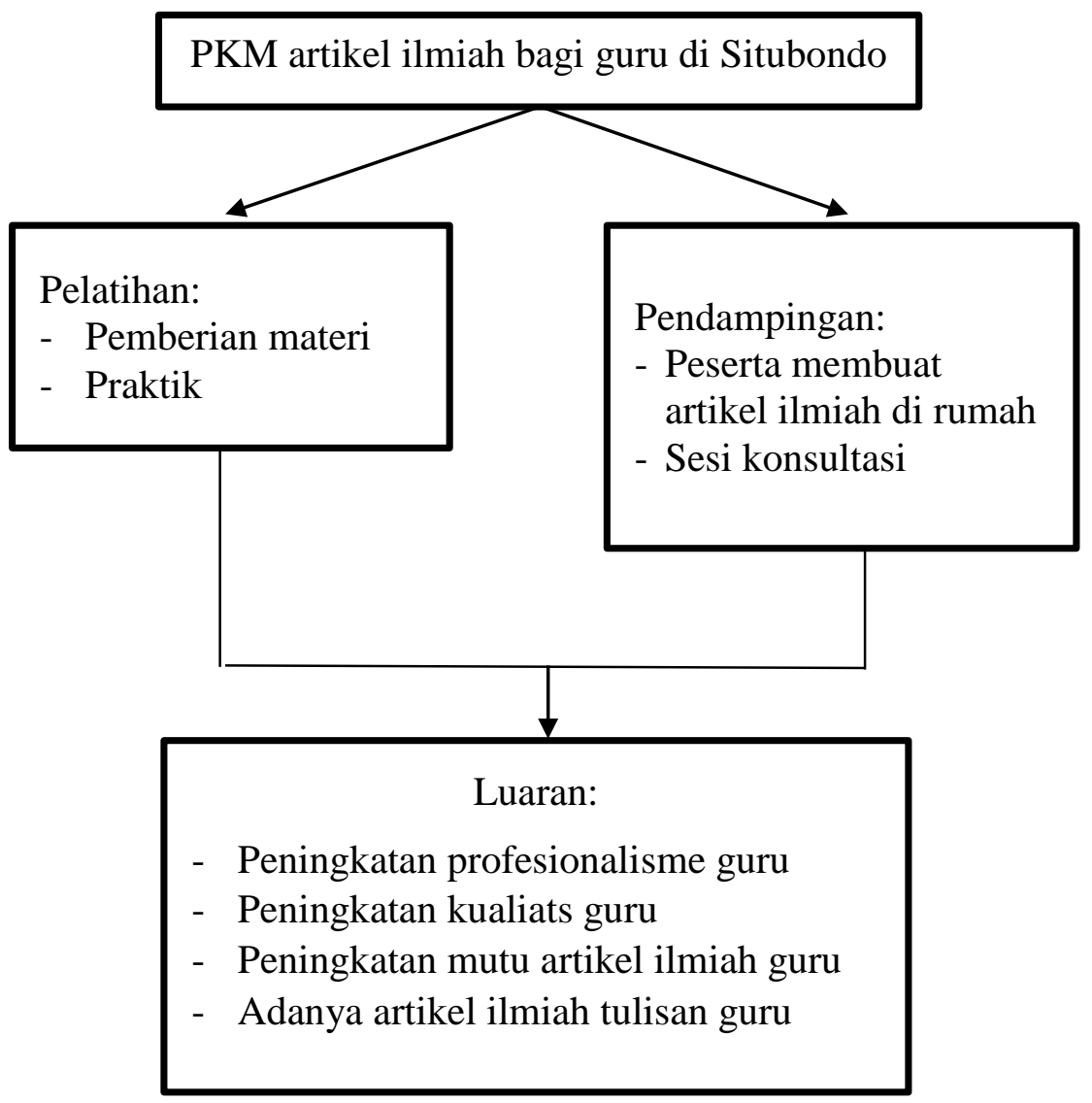

Gambar 1. Gambaran Iptek Kegiatan

\section{HASIL DAN PEMBAHASAN}

Tujuan utama dari diadakanya kegiatan PKM pelatihan penulisan artikel ilmiah ini secara umum adalah untuk meningkatkan kualitas guru dengan memberikan keterampilan menulis artikel ilmiah. Dengan keterampilan yang dimiliki, profesionalisme guru diharapkan juga meningkat. Secara khusus, kegiatan ini bertujuan untuk meningkatkan jumlah publikasi karya ilmiah guru-guru di Situbondo. Selain itu, kegiatan ini juga bertujuan memberikan kesempatan yang lebih luas bagi guru utamanya guruguru sekolah terpencil agar dapat memiliki wawasan dan pengetahuan yang lebih banyak tentang pentingnya menulis artikel ilmiah. Seperti yang telah dijelaskan sebelumnya, kegiatan ini dibagi menjadi dua yaitu tahap pelatihan dan tahap pendampingan. Berikut adalah paparan dan pembahasan dari hasil kegiatan. 


\section{Tahapan Pelatihan}

Tahap pelatihan dalam kegiatan ini diadakan selama satu hari yaitu pada hari Jumat, 18 April 2019 bertempat di ruang kelas Universitas Abdurachman Saleh Situbondo. Jumlah peserta yang hadir dalam kegiatan pelatihan ini adalah 26 orang peserta yang berasal dari SD Negeri 1 Sumberargo dan beberapa guru dari sekolah lain (SD, SMP, SMA, dan MA) yang berminat mengikuti pelatihan ini. Pelatihan ini berlangsung selama 8 (delapan) jam dari pukul 08:00 - 16:00 WIB dan dibagi menjadi 3 (tiga) sesi, yaitu sesi pemberian materi dan diskusi, sesi praktik, dan evaluasi.

\section{Pemberian Materi dan Diskusi}

Sesi ini berlangsung dari pukul 08:00 - 11:30. Pada sesi ini, peserta diberi materi tentang definisi dan jenis-jenis karya ilmiah. Materi yang diberikan pada pelatihan ini difokuskan pada materi tentang artikel ilmiah saja. Selain itu, peserta juga mendapatkan materi tentang sistematika dan etika penulisan artikel ilmiah, pelanggaran kode etik dalam penulisan artikel ilmiah, dan upaya menghindari plagiarisme.

Sesi ini diawali dengan pemberian materi mengenali konsep dan prosedur penulisan artikel ilmiah. Peserta diperkenalkan dengan kerangka umum artikel ilmiah, yaitu: latar belakang, tinjauan pustaka, metode penelitian, hasil dan pembahasan, dan kesimpulan dan saran. Peserta dibekali pengetahuan tentang apa yang harus mereka tulis dalam bagian-bagian artikel tersebut. Disampikan pula kepada peserta bahwa artikel ilmiah berasal dari kegiatan penelitian yang telah dilakukan oleh peserta. Artikel ilmiah juga dapat berupa hasil pemikiran konseptual. Dikarenakan semua peserta pelatihan adalah guru, maka peserta diwajibkan memiliki pemahaman yang cukup tentang penelitian pendidikan, utamanya Penelitian Tindakan Kelas (PTK). Pada sesi ini ditemukan fakta bahwa peserta merasa kesulitan dalam mengerjakan tinjauan pustaka. Hal ini dikarenakan kebiasaan membaca yang rendah. Selain itu, beberapa peserta beralasan tidak adanya referensi membuat mereka kesulitan menyusun artikel ilmiah. Maka dari itu, kami memberikan beberapa alternatif untuk masalah ini seperti memberikan alamatalamat website jurnal pendidikan, menunjukkan beberapa judul buku metode penelitian, dan membagikan beberapa contoh artikel penelitian pendidikan. Diharapkan peserta mendapatkan pencerahan dari sumber-sumber tersebut.

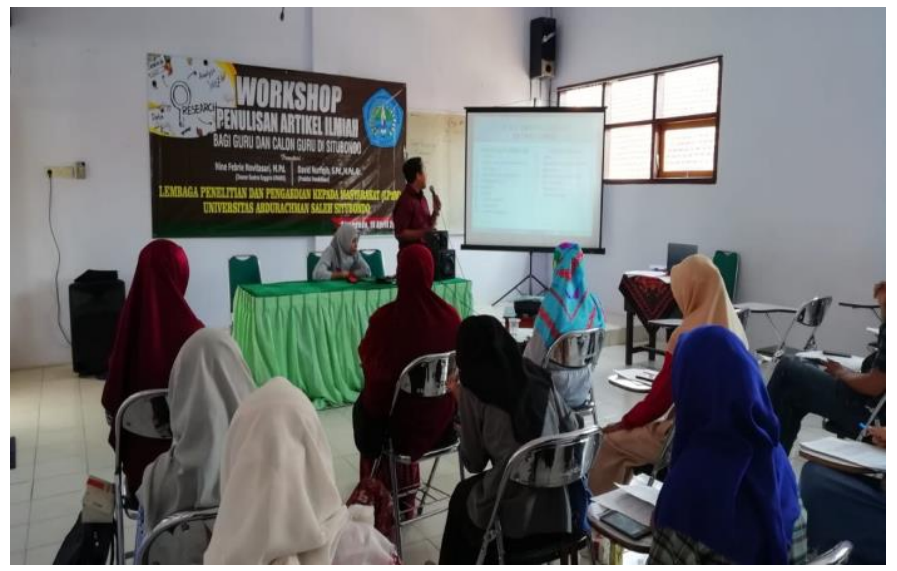

Gambar 2. Pemberian Materi 1 
Selanjutnya, peserta diberi materi tentang etika penulisan artikel ilmiah, termasuk masalah-masalah pelanggaran kode etik seperti plagiarisme, fabrikasi, dan falsifikasi. Plagiarisme adalah bentuk pelanggaran kode etik yang paling sering dilakukan oleh penulis artikel ilmiah, maka dari itu, peserta pelatihan harus dipastikan paham tentang pengertian jenis, penyebab, dan cara menghindari plagiarisme. Untuk menguji apakah peserta pelatihan pernah melakukan tindakan plagiarisme, sebuah quiz diberikan kepada peserta. Hasilnya menunjukkan bahwa peserta pernah melakukan tindakan plagiarisme baik tingkat ringan, sedang, maupun berat. Melihat fakta tersebut, peserta kemudian diberi materi tentang cara-cara yang dapat digunakan untuk menghindari plagiarisme, seperti mengutip, memparafrase, dan menggunakan aplikasi pendeteksi kemiripan tulisan (Turnitin, WCopyFind, Ithenticate). Beberapa peserta kemudian juga diberi latihan cara mengutip dan memparafrase tulisan untuk memastikan mereka paham cara mengutip dengan benar. Terakhir, peserta juga diberi materi tentang penulisan daftar pustaka yang benar sesuai dengan standar penulisan daftar pustaka yang biasanya digunakan oleh jurnal-jurnal ilmiah seperti APA, Harvard, ataupun Oxford. Untuk bagian ini, peserta juga diperkenalkan dengan dan aplikasi pengelola sitiran dan daftar pustaka seperti Mendeley, EndNote, dan Zotero. Namun sayangnya ada beberapa peserta yang kurang melek teknologi sehingga saat diminta mengunduh aplikasi dari Internet mereka sedikit mengalami kesulitan.

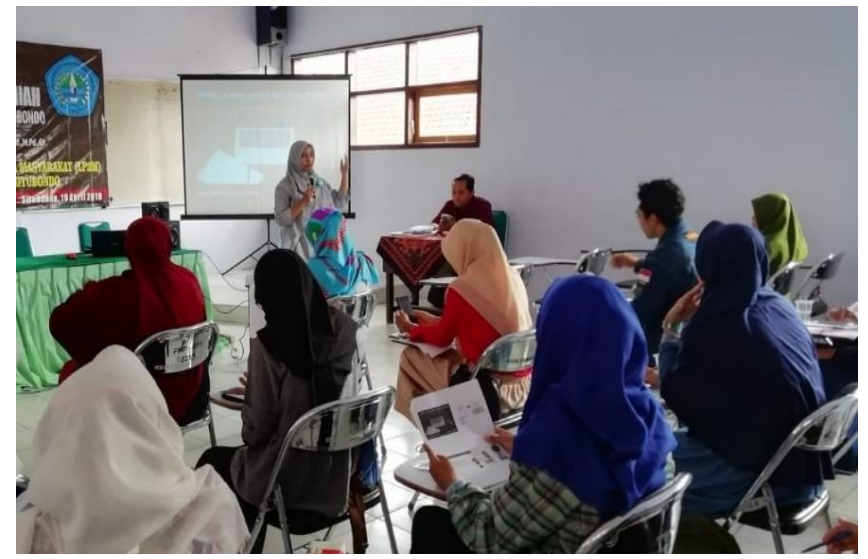

Gambar 3. Pemberian Materi 2

Jika dirangkum, secara umum, permasalahan yang ditemukan selama sesi pemberian materi adalah sebagai berikut:

1) Sebagian besar peserta (hampir $80 \%$ ) tidak bisa membedakan jenis-jenis karya ilmiah. Secara spesifik, permasalahan-permasalahan tersebut mencakup: a) Tidak bisa menyebutkan jenis-jenis karya ilmiah; b) Tidak bisa menyebutkan perbedaan antara artikel ilmiah dan makalah; c) Tidak bisa membedakan skripsi, tesis, dan disertasi.

2) Sebagian besar peserta (hampir 70\%) tidak bisa membuat rumusan masalah dan tujuan penelitian dengan benar. Indikator dari permasalahan ini adalah sebagai berikut: a) Bentuk rumusan masalah yang tidak dalam bentuk kalimat tanya; b) Rumusan masalah yang tidak jelas variabelnya; c) Penulisan rumusan masalah yang tidak konsisten; d) Penulisan rumusan masalahyang tidak lengkap.

3) Hampir semua peserta (hampir 100\%) tidak mengetahui tingkatan-tingkatan plagiarisme yang ditunjukkan dengan: a) Tidak bisa membedakan mana kegiatan yang 
dibolehkan dan tidak dibolehkan dalam menulis artikel ilmiah; b) Tidak bisa menulis kutipan/sitiran dengan benar; c) Tidak mengenal nama-nama aplikasi pendeteksi kemiripan dan aplikasi pengatur sitiran dan daftar pustaka.

Terkait dengan permasalahan di atas, sesi praktik dilaksanakan sebagai salah satu upaya penyelesaian. Sesi praktik berlangsung dari pukul 13:00 -16:00. Sesi praktik meliputi praktik membuat kerangka artikel ilmiah, seperti rumusan masalah, tujuan penelitian, batasan penelitian, dan manfaat penelitian. Masih banyak peserta pelatihan yang tidak bisa membuat rumusan masalah karena mereka tidak memiliki latar belakang yang cukup tentang jenis-jenis penelitian dan bentuk-bentuk rumusan masalahnya. Oleh karena itu, mereka harus selalu didampingi dalam sesi praktik ini. Sesi praktik juga mengharuskan peserta pelatihan berlatih menulis sitiran dan daftar pustaka dengan benar. Selain itu, peserta juga diberikan beberapa teks pendek dan diminta untuk berlatih memparafrase teks tersebut. dengan demikian, peserta bisa mengetahui mana proses parafrase yang legal dan mana parafrase yang masih tergolong plagiat. Parafrase legal adalah meminimalisir penggunana kata-kata yang sama persis dari sumber aslinya, sedangkan parafrase plagiat adalah penggunana kutipan langsung yang terlalu berlebihan dalam artikel yang kita buat. Terkait hal ini, disampaikan kepada peserta bahwa penggunana kutipan langsung yang diperbolehkan hanyalah $10 \%$.

Setelah melalui sesi praktik, hasil yang didapatkan adalah sebagai berikut:

1) Sekitar $60 \%$ peserta sudah bisa menuliskan rumusan masalah dengan benar.

2) Sekitar $70 \%$ peserta sudah bisa menuliskan kutipan/sitiran dengan benar.

3) Sebagian kecil peserta (sekitar 30\%) dapat menggunakan aplikasi pendeteksi kemiripan daring yang tersedia gratis di Internet seperti Grammarly.

4) Separuh dari peserta (sekitar 50\%) sudah bisa menggunakan teknik-teknik dasar aplikasi Mendeley.

Berdasarkan data di atas, dapat dilihat bahwa ada peningkatan keterampilan yang cukup baik yang telah ditunjukkan oleh peserta. Dengan adanya penjelasan yang diberikan secara cukup rinci dan lengkap, adanya modul dan contoh-contoh, serta kegiatan praktik yang langsung dilakukan, peserta lebih paham dan dapat menunjukkan indikator-indikator peningkatan keterampilan dalam penulisan artikel ilmiah. Namun, diakui bahwa hasil pelatihan belum sangat maksimal dikarenakan kegiatan ini hanya dilaksanakan dalam waktu sehari. Perlu waktu yang cukup lama untuk memberikan materi dan contoh-contoh yang lebih jelas dan lengkap, dan perlu beberapa sesi praktik agar peserta benar-benar dapat menngaplikasikan apa yang telah mereka dapat dari pemberian materi. Selain itu tidak semua peserta langsung sukses melakukan penginstalan aplikasi yang dipakai saat praktik. Namun bagaimanapun juga, adanya peningkatan ini patut diapresiasi karena peserta terlihat sangat antusias untuk belajar dan aktif dalam kegiatan pelatihan. 


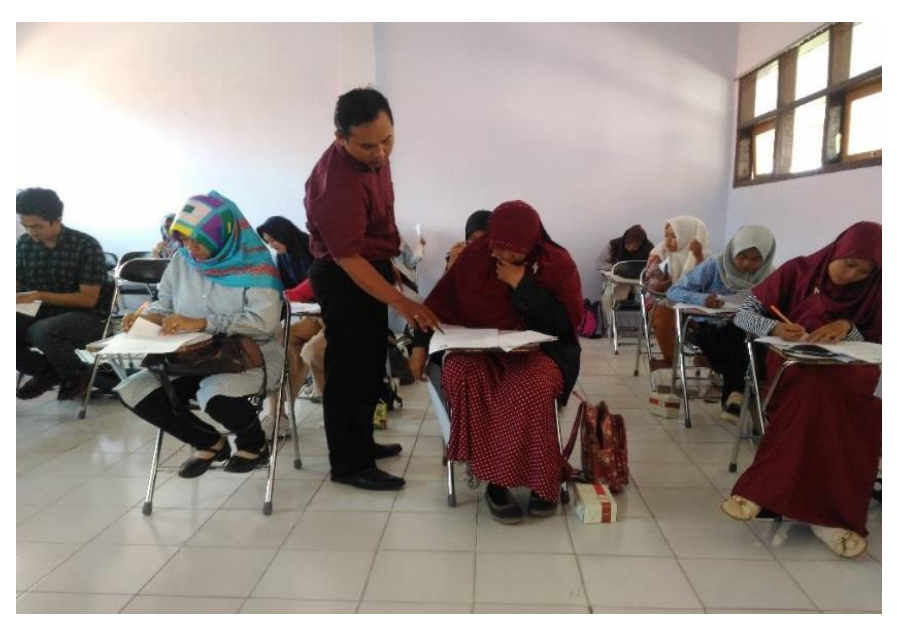

Gambar 4. Sesi Praktik

\section{Sesi Evaluasi}

Sesi evaluasi ini membahas apa saja poin-poin penting yang harus diperhatikan dan ditindak lanjuti selama pelatihan. Poin-poin tersebut adalah:

1) Pelatihan ini masih belum cukup bagi peserta karena cakupan bahasan yang sangat luas. Walaupun topik pelatihan adalah artikel ilmiah, namun semua aspek dari artikel ilmiah tidak dapat dijelaskan hanya dalam sekali pertemuan saja.

2) Terdapat beberapa peserta pelatihan yang masih butuh penjelasan lebih jauh tentang cara publikasi artikel ilmiah. Mereka berharap pihak penyelenggara pelatihan dapat membantu mereka mempublikasikan artikel ilmiah yang akan mereka buat.

3) Jika ada kesempatan lagi, sebaiknya peserta langsung diberi file installer aplikasi daripada diminta menngunduh sendiri dari Internet karena tidak semua peserta melek teknologi.

4) Plagiarisme adalah hal yang sangat berbahaya sehingga peserta harus diyakinkan, diberi pemahaman lebih, dan ditekankan agar tidak pernah sekali-kali melakukan plagiarisme karena itu selain merupakan pelanggaran kode etik juga akan membahayakan jenjang karir mereka.

5) Hasil praktik peserta sudah cukup bagus namun masih ada beberapa yang jauh dari sempurna. Pelatihan lebih lanjut diperlukan agar apa yang tidak sempat tercover dalam pelatihan ini dapat dibahas lebih lanjut.

6) Setelah pelatihan selesai, kegiatan tindak lanjut seperti pelatihan pembuatan Penelitian Tindakan Kelas (PTK) sangat disarankan untuk lebih memperdalam pemahaman guru tentang penelitian pendidikan, utamanya yang berhubungan langsung dengan kelas yang dipegang. 


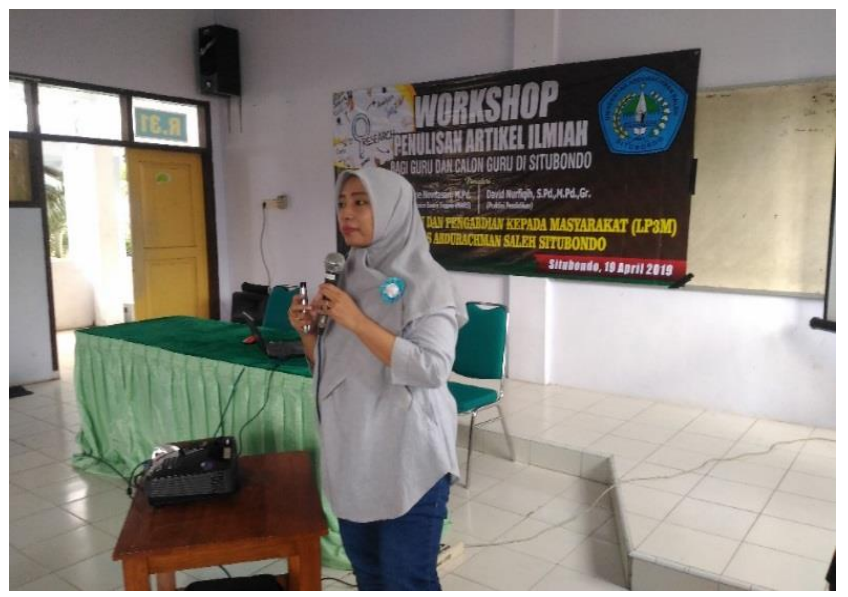

Gambar 5. Sesi Evaluasi

\section{Tahapan Pendampingan}

Tahapan pendampingan bagi peserta adalah selama tiga minggu, dari tanggal 18 April hingga 9 Mei 2019. Dalam tahap ini, peserta bebas untuk berkonsultasi melalui platform Whatss App maupun secara tatap muka langsung. Hanya ada beberapa guru yang berinisiatif untuk melakukan konsultasi, dan kebanyakan adalah guru yang masih muda. Artikel ilmiah yang dibuat hampir semuanya berasal dari Penelitian Tindakan Kelas (PTK). Namun bisa dilihat saat sesi konsultasi bahwa sudah ada perkembangan yang cukup baik dari sisi pemahaman peserta maupun kualitas artikel yang dibuat. Sebelumnya, masih banyak guru yang tidak bisa menuliskan kutipan dan daftar pustaka dengan benar. Banyak juga dari mereka yang tidak mengenal baik struktur penulisan artikel ilmiah. Bahkan, ada beberapa guru yang berpikir bahwa artikel ilmiah sama dengan artikel pada surat kabar. Namun, setelah melalui tahapan pelatihan dan pendampingan, pemahaman guru tentang manfaat dan keterampilan dalam menulis karya ilmiah sudah jauh lebih baik. Sampai artikel ini dibuat, terdapat 6 (enam) orang guru yang sudah berhasil membuat artikel ilmiahnya sendiri. Jumlah ini memang tidak besar, hanya (23\%) dari total jumlah peserta pelatihan. Namun bila dilihat, ini adalah sebuah pencapaian yang besar bila dibandingkan dengan keadaan sebelum diadakannya pelatihan dimana hampir semua peserta pelatihan belum paham tentang sistematika penulisan artikel ilmiah. Tabel 2 menunjukkan secara ringkas hasil dari kegiatan PKM ini.

Tabel 2. Target Capaian Kegiatan

\begin{tabular}{llccl}
\hline No & $\begin{array}{l}\text { Luaran yang } \\
\text { Ditargetkan }\end{array}$ & Tercapai & $\begin{array}{l}\text { Belum } \\
\text { Tercapai }\end{array}$ & Keterangan \\
\hline 1 & $\begin{array}{l}\text { Peningkatan } \\
\text { pemahamanan guru } \\
\text { tentang artikel ilmiah }\end{array}$ & $\sqrt{ }$ & $\begin{array}{l}\text { Adanya pemahaman tentang } \\
\text { manfaat penulisan artikel ilmiah } \\
\text { bagi guru }\end{array}$ \\
\hline 2 & $\begin{array}{l}\text { Peningkatan kualitas } \\
\text { guru }\end{array}$ & $\sqrt{ }$ & $\begin{array}{l}\text { Adanya peningkatan } \\
\text { profesionalisme guru dan calon } \\
\text { guru dalam bidang penelitian dan } \\
\text { karya ilmiah }\end{array}$ \\
\hline 3 & $\begin{array}{l}\text { Dihasilkannya artikel } \\
\text { ilmiah buatan guru }\end{array}$ & $\sqrt{ }$ & Adanya artikel ilmiah buatan guru \\
\hline
\end{tabular}




\section{SIMPULAN}

Dari kegiatan ini, terdapat beberapa kesimpulan yang dapat diambil. Pelatihan penulisan artikel ilmiah dapat meningkatkan kualitas dan profesionalisme guru. Selain itu, pelatihan penulisan artikel ilmiah ini juga memberikan pemahaman yang lebih baik kepada guru tentang manfaat dan penulisan artikel ilmiah. Manfaat lain yang didapat adalah peningkatan jumlah publikasi ilmiah yang dihasilkan guru. Untuk dampak jangka panjang, keterampilan menulis artikel ilmiah yang dimiliki guru dapat membantu meningkatkan jenjang karir mereka. Namun, hasil yang lebih maksimal akan didapat apabila pelatihan dan pendampingan dilaksanakan dalam rentang waktu yang lebih lama dengan tahap dan prosedur yang lebih rinci.

\section{UCAPAN TERIMA KASIH}

Pelaksana kegiatan mengucapkan terimakasih kepada pihak-pihak yang telah membantu terlaksananya kegiatan ini. Terimakasih kami sampaikan kepada: 1) P3M Universitas Abdurachman Saleh Situbondo yang telah mendanai kegiatan ini; 2) Mahasiswa-mahasiswa UNARS yang telah membantu dalam pelaksanaan pelatihan dan pendampingan; 3) SDN 1 Sumberrago sebagai mitra kegiatan; 4) Para guru yang telah berpartisipasi dalam kegiatan ini.

\section{REFERENSI}

Aina, M., Bambang, H., Retni, S. B., Afreni, H., \& Sadikin, A. (2015). Pelatihan penulisan karya tulis ilmiah bagi guru-guru SMA 8 Kota Jambi. Jurnal Pengabdian Pada Masyarakat Universitas Jambi, 30(3), 29-32.

Budiyanto, D. (2007). Mengenal karya ilmiah. Kuliah penulisan karya ilmiah. Yogyakarta: Universitas Negeri Yogyakarta.

Danawati, I. (2017). Problematika Guru dalam Menulis Karya Ilmiah sebagai Pengembangan Kompetensi Profesional di SD Muhammadiyah 5 Surakarta. Universitas Muhammadiyah Surakarta.

Dewi, C. A., Hendrawani, H., Kurniasih, Y., Suryati, S., \& Khery, Y. (2018). Optimalisasi peningkatan profesionalisme guru-guru melalui pelatihan penulisan karya ilmiah. Lumbung Inovasi: Jurnal Pengabdian kepada Masyarakat, 3(1), 20-26.

Direktorat Jenderal Pendidikan Dasar dan Menengah. (2018). SD Negeri 1 Sumberargo. Retrieved March 18, 2019, from http://dapo.dikdasmen.kemdikbud.go.id/sekolah/BF45FC64099D6E8B0715

Gunawan, I., Triwiyanto, T., \& Kusumaningrum, D. E. (2018). Pendampingan penulisan artikel ilmiah bagi para guru sekolah menengah pertama. Abdimas Pedagogi: Jurnal Ilmiah Pengabdian kepada Masyarakat, 1(2), 128-135. 
Ilfiandra, Suherman, U., Akhmad, S. N., Budiamin, A., \& Setiawati. (2016). Pelatihan dan pendampingan penulisan karya tulis ilmiah bagi guru SD. Jurnal Pengabdian Pada Masyarakat, 1(1), 70-81. doi: 10.30653/002.201611.10

Imswatama, A., Arvianto, F., \& Supendi, D. A. (2018). Meningkatkan kompetensi profesional guru SMP Negeri 7 Kota Sukabumi melalui pendampingan penyusunan karya ilmiah. E-Dimas, 9(1), 134. doi: 10.26877/e-dimas.v9i1.1608

Nailun, F. (2018). Menulis artikel ilmiah. Retrieved September 2, 2019, from https://www.kompasiana.com/fazanailun4094/5bfd5836c112fe5ad80a5432/menulisartikel-ilmiah?page=all

Raharja, H. (2013). Menulis artikel ilmiah, tantangan atau ancaman bagi guru. Retrieved September 2, 2019, from https://www.kompasiana.com/hidayatraharja/55295807f17e6156638b4568/menulisartikel-ilmiah-tantangan-atau-ancaman-bagi-guru

Sumartini, S., Mulyani, M., \& Nugroho, B. A. (2019). Workshop penulisan karya ilmiah bagi guru sekolah dasar di kabupaten Demak. Jurnal Puruhita, 1(1), 54-59.

Trisniawati, Wardani, K., \& Azizah, D. M. (2018). Optimalisasi penulisan karya tulis ilmiah pada guru SD Negeri Jetis 2 Yogyakarta. Abdimas Dewantara, 1(1), 77-86. doi: 10.30738/ad.v1i1.2086 